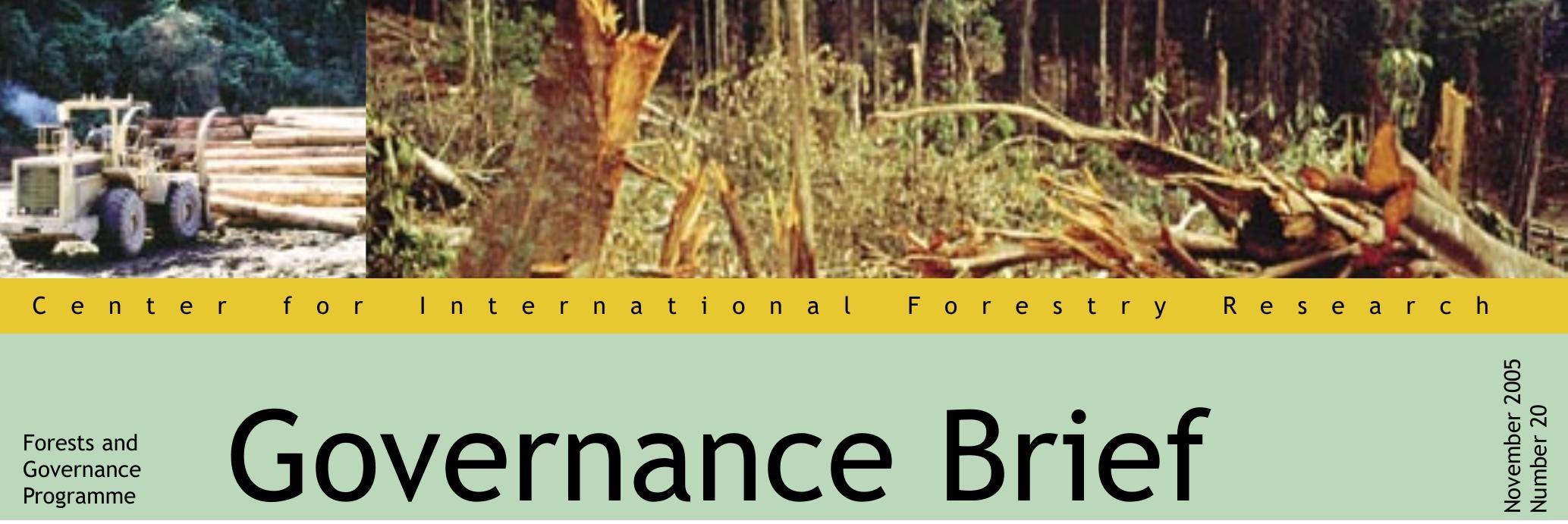

\title{
KYC Principles \\ For Forestry Related Customers
}

\author{
Bambang Setiono \\ Policy and Financial Analyst, Center for International Forestry Research (CIFOR)
}

\section{Banks are obligated to help stop illegal forest activities}

Weaknesses in the banking system of a country, whether developing or developed, can threaten financial stability both within, and beyond that country. The Basel Committee on Banking Supervision issued the Basel Core Principles in order to strengthen financial systems. One of the important Core Principles is to protect banks from being used by criminals. It requires banking supervisors to make sure that banks have adequate policies, practices and procedures in place, including strict "Know Your Customer" (KYC) rules. This is to detect and prevent criminal activity or fraud, and ensure that suspicious transactions are reported to the appropriate authorities. This principle supports international cooperation against money laundering crimes.

Illegal logging and other forestry crimes are among serious crimes should be stopped by banks and other financial service providers. Fighting forestry crime has become a growing international concern over the past five years. ${ }^{1}$ It remains a top priority of the Indonesian government under the administration of Susilo Bambang Yudhoyono.

Some of those involved in illegal logging activities may be customers of banks and other financial service providers. Timber-based industries are suspected of receiving and using illegal timber since their demand is three times greater than the legal supply of available timber. Indonesian timberbased industries have an installed capacity of more than 60 million $\mathrm{m}^{3}$ per year. Indonesia's wood panel producers harvest roughly 20 million $\mathrm{m}^{3}$ of round wood annually while unofficially harvesting a similar volume. Pulp industries harvest another 20 million $\mathrm{m}^{3}$ per year, and will continue to harvest increasing amounts every year. The demand for timber has far exceeded the sustainable level of wood supply, which stood at 25 million $\mathrm{m}^{3}$ per year in $1999 .{ }^{2}$ With the Soft-Landing Policy, the Minister of Forestry set much lower, wood supply targets of 6.89 million $\mathrm{m}^{3}$ for 2003 and only 5.7 million for 2004 .

Both local and international banks have financed timber-based industries in Indonesia. Before the Indonesian financial crisis of 1997, Indonesian national banks granted more than US\$4 billion in loans to Indonesian timber industries, which also received more than US\$7 billion in short-term loans and long-term financing from international financial institutions (Setiono 2005). All the top ten national banks in Indonesia financed timber industries. These banks included the former state banks that have now merged to become Bank Mandiri, Bank Danamon, Bank Umum National (now closed by the government) and Bank International Indonesia. International institutions, Credit Suissee First Boston, ING Bank N.V. and Credit Lyonnais of Singapore have also financed timber extraction in Indonesia. Besides these, by 1999 four Dutch banks - ABN-AMRO Bank, ING Bank, Rabobank and Mees Pierson - had invested in 740,000 ha of oil palm plantations in Indonesia (Wakker et al. 2000). Since the early $1990 \mathrm{~s}$, private international financial institutions have also played a critical role in facilitating the rapid expansion of the Indonesian pulp and paper industries. These institutions were responsible for channelling over US\$12 billion to the industries by 1999 (Barr 2001). 


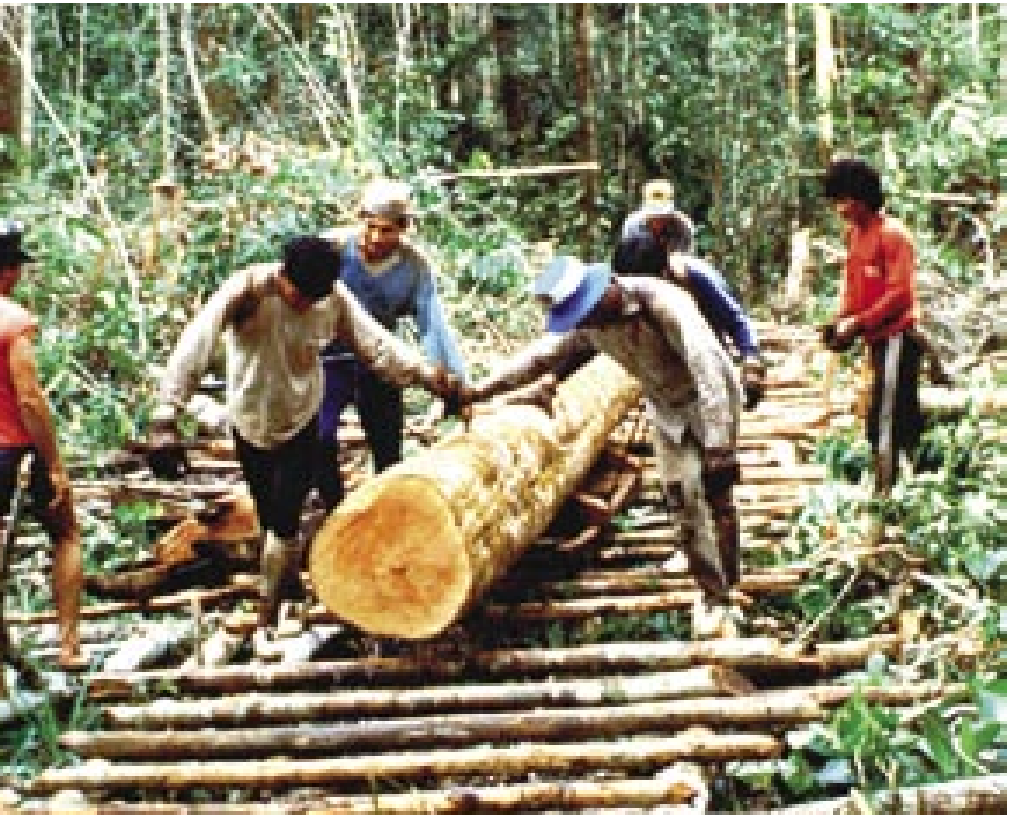

\section{The KYC principle}

The KYC principle requires banks and other financial service providers (FSPs) to have systems to identify their customers, to understand their purpose in opening a relationship with the bank, to know customer's sources of funds and wealth, to develop customer business profiles, and to monitor their business relationships. Banks should make sure that no criminals or suspected criminals deposit the proceeds of illegal businesses into the banking system. Banks are required to maintain profiles of their customers, including their timber customers, and the pattern of their transactions. In Indonesia, this requirement became applicable to existing and new customers following the introduction of the KYC regulation in December 2001.

Banks are required to conduct 'customer due diligence' (CDD) in order to maintain profiles of their customers. These profiles should at the very least contain information on customers' identities, employment or business, normal incomes, other accounts they have, normal financial transactions, and their purpose in opening an account with the bank. ${ }^{3}$ Moreover, the bank's board of directors is also required to establish criteria for determining high-risk countries, businesses and customers. ${ }^{4} \mathrm{~A}$ high-risk country is one that has not adopted provisions for the KYC principle; a high-risk business is a line of business that may potentially be exploited for money laundering; and a high-risk customer is an individual that may potentially be involved in money laundering. Suspicious financial transactions usually come from transactions involving these high-risk entities.
The KYC regulation requires banks to conduct identification and verification, for both individual and corporate customers, using the supporting documents provided by the prospective customer. This process includes conducting extensive due diligence on any prospective customer, including state officials, operating in a high-risk country, in a high-risk business, or deemed to be a highrisk customer. For corporate customers, banks are also required to assess the plausibility of information pertaining to the company's line of business, its financial statements, descriptions of its business operations, its transaction profile, business turnover, company location, and so on.

The KYC regulation also requires banks to monitor the accounts and transactions of their customers. This process includes identifying any possible entries or transactions (cash or non-cash) incompatible with the customer's profile. Banks are required to conduct intensive monitoring of high-risk customers. ${ }^{5}$

When this system works well, banks and other FSPs can identify (know) suspicious transactions (STR) involving their customers. A suspicious financial transaction takes place when a customer conducts or cancels a financial transaction using assets reasonably suspected to have arisen from criminal proceeds, or if the financial transaction deviates from usual patterns. ${ }^{6}$ The KYC principle requires banks having STR information to report to the financial intelligence unit, here in Indonesia called the Indonesian Financial Transaction Reports and Analysis Centre (PPATK). ${ }^{7}$ This reporting obligation does not require FSPs to have knowledge about crimes committed by their customers. Banks and other financial service providers do not need to know whether funds used in financial transaction come from forestry crimes or any other crimes. However, they are obligated to report if customers are involved in suspicious financial transactions and if they suspect the customers are involved in money laundering crimes.

\section{STR related to illegal forest activities}

There are several points of interaction between banks and timber customers that should trigger proper customer due diligence (CDD) by banks before finally reporting STRs to PPATK:

- Banks (FSPs) provide financial and banking facilities to legal timber companies that might use illegal logs for producing timberbased products such as pulp, plywood sawnwood, and furniture. 
- Timber customers carry out large cash transactions, especially cash withdrawals. Intellectual actor with strong financial supports (or known as cukong) involved in illegal logging will need large sums of cash to provide advance payments to groups of loggers who will enter the forest for weeks at a time. The Cukong needs to pay the suppliers who will then provide food, chainsaws and heavy equipment to the loggers. They also need to pay tugboats or ships to transport the timber to the market. If a cukong wants to get a licence or protection from powerful individuals in the local government or law enforcement offices, he must pay bribes. In most cases the cukong will pay all these expenses in cash.

- Timber customers may receive transfer payments from abroad. The cukong may receive transfer payments from buyers when illegal logs are exported (or smuggled).

- Timber customers may make transfers to pay for the logistics of logging operations that can only be provided by suppliers in Java, or they have to make transfers to their key contacts' accounts when paying bribes to powerful individuals in Jakarta.

In all these instances, banks need to undertake proper CDD.

In addition to illegal logging, banks need also to be aware of the level of corruption in Indonesia. Several reports have suggested that Indonesia is the most corrupt country in Asia. ${ }^{8}$ Banks must interact with government and law enforcement officers both at the local and national levels. The Financial Action Task Force (FATF) on money laundering has defined government officials as Politically Exposed Persons (PEP). The Indonesian money laundering regulators have not yet issued a KYC regulation for PEPs, but the FATF has recommended that financial institutions conduct enhanced CDD on PEPs to assure the funds managed by financial institutions on behalf on the PEPs do not derive from corrupt sources. ${ }^{9}$ It is impossible for illegal logging to occur without the support of corrupt government and law enforcement officers. Therefore, banks and other FSPs need to conduct proper CDD when they provide banking and financial services to government and law enforcement officers, especially those working in forested regions who are high-risk customers with respect to illegal logging.

Banks should be concerned not only with illegal logging and corruption, but also with banking fraud. Forestry companies might apply transfer pricing to move their foreign earnings to their

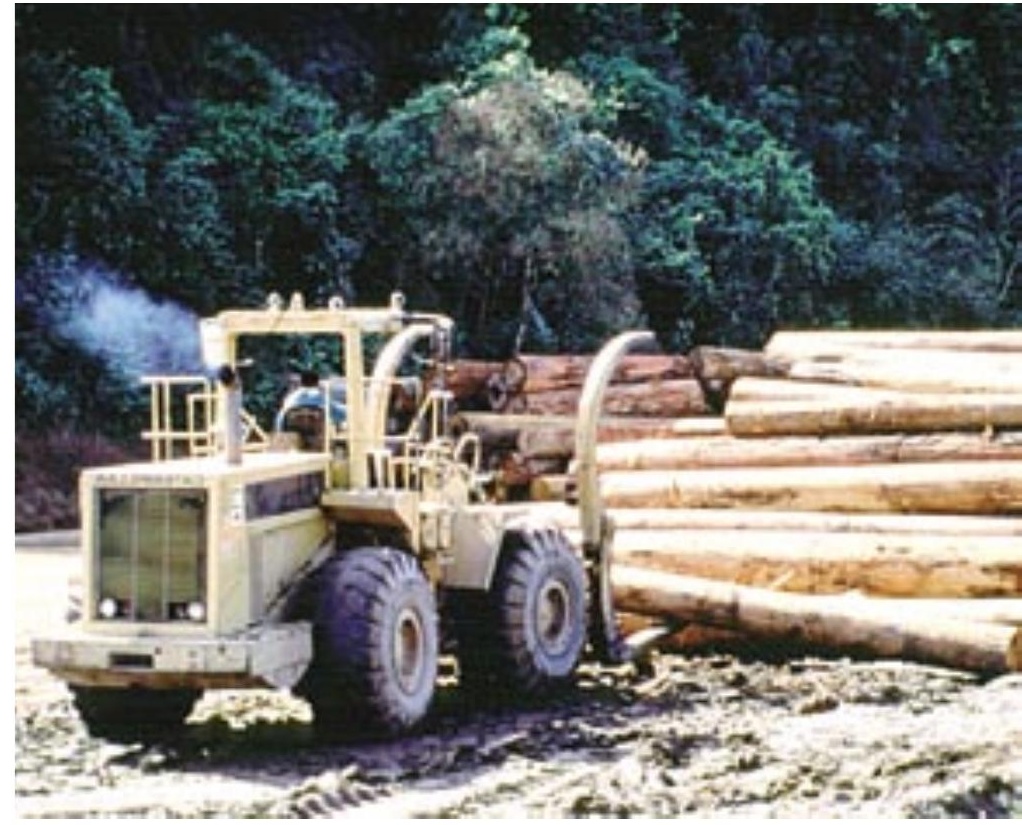

interests abroad, ignoring debt agreements or debt covenants with banks and other creditors. With artificially poor earnings, they can then look for debt restructuring opportunities to write-off their debts. Under pressure from the government policy to support the timber industries, banks can write-off some of their debts, can suffer significant losses, and can have lower capital adequacy ratios.

Banks should conduct proper due diligence on transactions by timber industries involving exports or loans to affiliated companies, or buyers located in high-risk financial jurisdictions such as the Cayman Islands. When there is suspicion that a customer wants to move his foreign earnings abroad, banks should file an STR to PPATK.

\section{Progress in implementing the KYC principle}

A bank or FSP can have knowledge for use in STRs and reasonable suspicion on money laundering crimes based on information from many sources, including but not limited to law enforcement agencies (for example, police investigators and state prosecutors), government institutions (for example, the Ministry of Forestry and the Ministry of Environment), civil society (forestry NGOs), the media, financial regulators (for example, Bank Indonesia), PPATK, and its own records. Since many illegal logging and corruption cases in the forestry sector have become public information, FSPs should have reported customers connected to illegal logging crimes to PPATK. 
${ }^{5}$ Bank Indonesia Circular Letter No. 5/32/ DPNP regarding the Guidelines for the Standard Implementation of the Know Your Customer Principle, December 2003.

${ }^{6}$ Article 1.7, Law No. 25/2003.

7 Article 13.2, Law No. 25/2003.

${ }^{8}$ The Corruption Index of 2004 by The Political and Economic Risk Consultancy, a Hong Kongbased risk consultancy.

9 Politically exposed persons (PEP) apply to individuals who are, or have been entrusted with prominent public functions in a foreign country, for example heads of state or government, senior politicians, senior government officials, judicial or military officials, senior executives of state-owned corporations, important political party officials. Business relationships with family members or close associates of PEPs involve reputational risks similar to those with PEPs themselves (FATF Money Laundering, Glossary: FATF 40 Recommendations).

${ }^{10}$ By October 2005, PPATK can only submit 7 (seven) reports related to illegal logging to the police. None of these reports has been processed to the court.

${ }^{11}$ Bank Indonesia Regulation (PBI) No.3/10/ $\mathrm{PBI} / 2001$ regarding implementation of the KYC Principle, issued in June 2001. Bank Indonesia issued $\mathrm{PBI}$ No. 3/23/PBI/2001 to improve on PBI No.3 in December 2001 and Bank Indonesia Circular Letter No.6/37/DPNP regarding Assessment and Imposition of Sanctions in regard to the application of the KYC principle and other requirements pertaining to the Law on Money Laundering Crime, 10 September 2004 


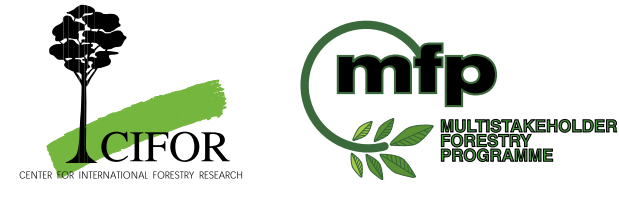

Center for International Forestry Research, CIFOR Office: Jalan CIFOR, Situ Gede, Sindang Barang, Bogor Barat 16680, Indonesia.

Mailing: P.O. Box. 6596 JKPWB, Jakarta 10065, Indonesia
Tel: +62(251) 622622 Fax: +62(251) 622100

E-mail: cifor@cgiar.org Website: www.cifor.cgiar.org

Front page photos: Douglas Sheil and Miriam Van Heist

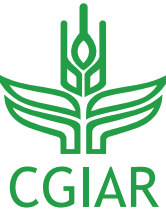

F U T U R E HAR $/ /$ E S T

CIFOR's Forests and Governance Programme examines how decisions about forests and forest-dependent people are made and implemented in order to promote the participation and empowerment of disadvantaged groups; the accountability and transparency of decision-makers and more powerful groups; and democratic, inclusive processes that support fair representation and decision making among all groups. 